\title{
The Influence of Profitability and Leverage on Corporate Social Responsibility Disclosure
}

\author{
Valendra Smaut Kapitan \\ Faculty of Economics \\ Universitas Widyatama \\ Syafrizal Ikram \\ Faculty of Economics \\ Universitas Widyatama
}

\begin{abstract}
This study aims to examine the influence of profitability and leverage on corporate social responsibility disclosure. The study was conducted in companies listed in Indonesia Stock Exchange. Profitability and leverage were treated as independent variables, while disclosure of corporate social responsibility is the dependent variable. The research method was used in this research is a verificative approach. The population in this study is the companies listed in Indonesia Stock Exchange. Sample of the study is the companies included as a member of LQ 45 index for period 2013-2015. Total listed companies were involved in this study is 67 companies. The sampling technique used in this study is nonprobability sampling with the purposive sampling method. The data analysis used in this study is multiple linear regression analysis at a significance level of 5\%. The statistical program was used in analyzing data is Eviews version 8. The results showed that profitability influences corporate social responsibility disclosure. However, leverage does not influence corporate social responsibility disclosure. Simultaneously, profitability and leverage influence corporate social responsibility disclosure
\end{abstract}

Keywords: Profitability; Leverage; Disclosure; Corporate Social Responsibility

\section{Introduction}

The management of the company seeks to implement good governance by accommodating the interests of all parties. The increasing trend of good governance practice has improved the company's response toward social responsibilities. Furthermore, it raises public awareness so that the company is subject to pressure and demands from society. Initially, the management only has a responsibility to manage the organization only. However, nowadays, with stakeholders being strategic issues for the existence of a business organization, the management has to include social responsibility as an important aspect should be managed. Since then, the concept of social responsibility arises and being popular (Masnila, 2010). The business activities, either directly or indirectly, can affect environmental quality through waste and pollution. The implementation of corporate social responsibility is compensation of harmfull effect of business activities to the 
environment and community. John Elkington introduced the concept of the Triple Bottom Line (TBL) and it refers to profit, people, and the planet. Corporate Social Responsibility (CSR) implies that the business organization is not only pursuing profits only but also responsible for the social (People), and its environment (Planet). CSR is indispensable in the business world and is a pillar in measuring the success of a company (Hadi, 2011:56).

Eipsten and Freedman in Cheng and Christiawan (2011) explained that there were many benefits of CSR disclosure for the business organization. Improving competitive advantage, increasing the trust of shareholder and stakeholders are some of the example the benefits of CSR. Even though the popularity of CSR is increasing lately, however, the practice of CSR program in the business organization still poor (Haramain, 2016). Furthermore, the accountability of the CSR program was found not transparent (Daniri, 2005). There are several rationalizations that business organizations should implement CSR activities. The company is part of the community. It is reasonable when the company pays attention to the public interest. Business organization and society have symbiotic properties of mutualism. A business organization can not survive without the existence of society. Therefore, the companies should give back the benefits such as profits obtained through the CSR program. Furthermore, CSR activities can avoid social conflicts due to the negative impact of business organization operation ( pollution and waste)

The company has goals and targets to achieve. As part of the community, the company interacts with other community members in every activity. It is because the company is a subsystem of community life, so it requires the regularity of interaction patterns with sub-Other systems. The existence of the company cannot be separated with the interests of the wider community (stakeholders). The company is a party that utilizes resources, which is potentially cause Social and environmental problems. The company has benefited from the utilization of such resources, while the community that bears the negative consequences. It has become the responsibility of the company to distribute some of the profits gained for the welfare of the community, repair the damage caused, and give reciprocal value to the stakeholders. This reason causes social responsibility to be an integral part of the company's operations (Hadi, 2011:99).

Some of the issues that arise related to the company existence are less concerned about the environmental and social conditions surrounding it. There are only about 25 companies that conduct the disclosure of corporate social responsibility of 438 companies listed on the Indonesia Stock Exchange ( Darwin, 2011). It is relatively low the participation of the listed companies in disclosing CSR reporting. Therefore, there is a need to understand the factors that influence CSR disclosure. Purpose of the study is to examine the influence of financial aspects, namely profitability and leverage on CSR disclosure.

\section{Literature Review}

Corporate social responsibility is the commitment of the company to contribute to the development of sustainable economies concerning corporate social responsibility and focused on the balance of the economic, social, and environmental aspects (fortunately, 2008:42). Corporate social responsibility is a business commitment to act ethically, operate legally and contribute to the improvement of the improving the quality of life of employees and their families, local communities and the wider community (Budimanta, Prasetijo, \& Rudito (2004:38). As part of transparency and accountability to the stakeholders, the management of the 
company is expected to conduct CSR disclosure. CSR disclosure is the delivery of information on the social and environmental impacts of the company's economic activities aimed at stakeholders and society as a whole as a form of CSR (Adebayo, 2000).

In Indonesia context, CSR reporting is governed by law No. 40 the year 2007. In that law, the limited liability companies related to the natural resources must disclose corporate social responsibility information. The law requires all the company to report the implementation of social responsibility and the environment in the annual report. The reporting is a reflection of the need for corporate accountability for the implementation of social and environmental responsibility so that stakeholders can assess the implementation of the activities. The Law of Limited Liability article 74 paragraph (1) mentions that the company carrying out business activities related to natural resources must carry out social and environmental responsibility. Limited liability Law Article 66 paragraph (2) which requires the company to report social responsibility activities in its annual report. The law No. 32 of 2009 on environmental protection and management also governs that any person who does business activity is obliged to provide information relating to the protection and management of the environment.

In the international context, the guidelines for the joint reference of social responsibility reports have been developed by the Global Reporting Initiatives (Elka, 2014). Global Reporting Initiatives (GRI) is an international standard for preparing social responsibility reports. Lindblom in Deegan et al. (2002) states one of the CSR disclosure media is through an annual report, which is an essential tool for obtaining information about financial conditions and non-financial information that have been achieved Company. Main factors for gaining attention from the investors is profitability and leverage. It provides information to analyze and assess financial conditions as well as the potential of the company (Munawir (2004:31)

According to Heinze (1976) in Anggraini (2006), profitability is a fundamental factor that makes management have the flexibility to spend financial resources for conducting social responsibility activities. According to Yuliana et al. (2008), the high level of profitability encourages managers to provide more detailed information about their social programs. Belkaoui and Karpik in Maiyarni et al. (2014) explained that the higher the leverage, the more likely the company will be experiencing a breach of debt contracts, then the manager will strive to report the profit is now higher than the future profit. The reported profit must be high, then the manager reduces costs, including fees for disclosing social information as a form of social responsibility. The management of the company with high leverage will reduce the disclosure of social responsibility he made in order not to be the highlight of the Debtholders (Wardani, 2013). The results of the research conducted by Daryono and Zulhelmy (2012) showed a significant influence between leverage and corporate social responsibility.

\section{Research methods}

The object of this research is the profitability, Leverage, and Disclosure of Corporate Social Responsibility. Meanwhile, the company listed on the Indonesia Stock Exchange is subject of the study. The population in this study is the annual report of the listed company in Indonesia Stock Exchange company based on the LQ 45 index throughout 3 (three) years, from 2013 to 2015 . The following presented in Table 1 is a list of companies included in the index LQ 45 the year 2013 $-2015$. 
Table 1. LQ 45 Companies for the period 2013 - 2015

\begin{tabular}{|c|c|c|}
\hline No. & Company code & Company Name \\
\hline 1 & AALI & Astra Agro Lestari Tbk PT \\
\hline 2 & ADHI & Adhi Karya (Perseo) Tbk PT \\
\hline 3 & ADRO & Adaro Energy Tbk \\
\hline 4 & AKRA & AKR Corporindo Tbk PT \\
\hline 5 & ANTM & Aneka Tambang Tbk PT \\
\hline 6 & ASII & Astra International Tbk \\
\hline 7 & ASRI & Alam Sutera Realty Tbk \\
\hline 8 & BBCA & Bank Cetral Asia Tbk PT \\
\hline 9 & BBNI & Bank Negara Indonesia (Persero) Tbk \\
\hline 10 & BBRI & Bank Rakyat Indonesia (Persero) Tbk \\
\hline 11 & BBTN & Bank Tabungan Negara (Persero) Tbk \\
\hline 12 & BDMN & Bank Danamon Indoneisa Tbk \\
\hline 13 & BHIT & Bhakti Investama Tbk \\
\hline 14 & BJBR & BPD Jawa Barat \& Banten Tbk \\
\hline 15 & BKSL & Sentul City Tbk PT \\
\hline 16 & BMRI & Bank Mandiri (Persero) Tbk \\
\hline 17 & BMTR & Global Mediacom Tbk PT \\
\hline 18 & BSDE & Bumi Serpong Damai Tbk PT \\
\hline 19 & BUMI & Bumi Resources Tbk \\
\hline 20 & BWPT & BW Plantation Tbk \\
\hline 21 & CPIN & Charoen Pokphan Indonesia Tbk \\
\hline 22 & CTRA & Ciputra Development Tbk \\
\hline 23 & DOID & Delta Dunia Makmur Tbk \\
\hline 24 & ELSA & Elnusa Tbk \\
\hline 25 & EXCL & XL Axiata Tbk \\
\hline 26 & GGRM & Gudang Garam Tbk \\
\hline 27 & GIAA & Garuda Indonesia (Perseo) Tbk \\
\hline 28 & HMSP & H. M. Sampoerna Tbk \\
\hline 29 & HRUM & Harum Energy Tbk \\
\hline 30 & ICBP & Indofood CBP Sukses Makmur Tbk \\
\hline 31 & IMAS & Indomobil Sukses International Tbk \\
\hline 32 & INCO & Vale Indonesia Tbk \\
\hline 33 & ICBP & Indofood CBP Sukses Makmur Tbk \\
\hline 34 & INDF & Indofood Sukses Makmur Tbk \\
\hline 35 & INTP & Indocement Tunggal Perkasa Tbk \\
\hline 36 & ITMG & Indo Tambangraya Megah Tbk \\
\hline 37 & JSMR & Jasa Marga (Persero) Tbk \\
\hline 38 & KLBF & Kalbe Farma Tbk \\
\hline 39 & LPKR & Lippo Karawaci Tbk \\
\hline 40 & LPPF & Matahari Department Store Tbk \\
\hline 41 & LSIP & PP London Sumatera Indonesia Tbk \\
\hline 42 & MAIN & Malindo Feedmill Tbk \\
\hline
\end{tabular}




\begin{tabular}{|c|c|c|}
\hline 43 & MAPI & Mitra Adiperkasa Tbk \\
\hline 44 & MLPL & Multipolar Tbk \\
\hline 45 & MNCN & Media Nusantara Citra Tbk \\
\hline 46 & MPPA & Matahari Putra Prima Tbk \\
\hline 47 & PGAS & Perusahaan Gas Negara (Persero) Tbk \\
\hline 48 & PTBA & Tambang Batubara Bukit Asam (Persero) Tbk \\
\hline 49 & PTPP & PP (Persero) Tbk \\
\hline 50 & PWON & Pakuwon Jati Tbk \\
\hline 51 & SCMA & Surya Citra Media Tbk \\
\hline 52 & SILO & Siloam International Hospital Tbk \\
\hline 53 & SMCB & Holcim Indonesia Tbk \\
\hline 54 & SMGR & Semen Indonesia (Persero) Tbk \\
\hline 55 & SMRA & Summarecon Agung Tbk \\
\hline 56 & SRIL & Sri Rejeki Isman Tbk \\
\hline 57 & SSMS & Sawit Sumbermas Sarana Tbk \\
\hline 58 & SSIA & Surya Semesta Internusa Tbk \\
\hline 59 & TAXI & Express Transindo Utama Tbk \\
\hline 60 & TBIG & Tower Bersama Infrastructure Tbk \\
\hline 61 & TLKM & Telekomunikasi Indonesia (Persero) Tbk \\
\hline 62 & UNTR & United Tractors Tbk \\
\hline 63 & UNVR & Unilever Indonesia Tbk \\
\hline 64 & VIVA & Visi Media Karya Tbk \\
\hline 65 & WIKA & Wijaya Karya Tbk \\
\hline 66 & WSKT & Waskita Karya (Persero) Tbk \\
\hline 67 & WTON & Wijaya Karya Beton Tbk \\
\hline
\end{tabular}

Source: www.idx.co.id

This study used the purposive sampling method, and it refers to sampling techniques based on specific criteria or considerations (Sugino, 2012:126). The criteria used in this study are as follows; 1 ) Companies listed on the Indonesia Stock Exchange by index LQ 45 period 2013 2015, 2) Companies listed on the Indonesia Stock Exchange and consistently registered
LQ index 45 periods 2013 - 2015. These criteria were used to determine the number of companies taken from the total company listed on the Indonesia Stock Exchange based on the index LQ 45 period 2013 2015. Based on the criteria previously determined, the comprehensive information about the sample selection is presented in Table 2.

Table 2. Research sample Selection

\begin{tabular}{|c|l|c|}
\hline No & \multicolumn{1}{|c|}{ Sample criteria } & Amount \\
\hline 1 & $\begin{array}{l}\text { Companies listed on the Indonesia Stock Exchange by index LQ 45 } \\
\text { period 2013 - 2015 }\end{array}$ & 67 \\
\hline 2 & $\begin{array}{l}\text { Companies listed on the Indonesia Stock Exchange and consistently } \\
\text { registered LQ index 45 periods 2013 - 2015 }\end{array}$ & 26 \\
\hline Number of companies according to criteria & 26 \\
\hline \multicolumn{2}{|c|}{ Total Samples: 26 Companies x 3 years } & 78 \\
\hline
\end{tabular}


Table 3 shows 67 (sixty-seven) companies listed on the Indonesia Stock Exchange have been included in the category of LQ 45 index during the 2013 2015 period. The selection generates 78 (seventy eiqth) annual reports derived from 26 (twenty-six) companies with observations for 3 (three) years. The list of companies used in the study is as follows

Table 3. List of companies used in research

\begin{tabular}{|c|l|l|}
\hline No & \multicolumn{1}{|c|}{ Company code } & \multicolumn{1}{c|}{ Company Name } \\
\hline 1 & UAL & PT. Astra Agro Lestari Tbk \\
\hline 2 & Churchyard & Adaro Energy TBK \\
\hline 3 & AKRA & AKR Corporindo TBK PT \\
\hline 4 & Asia & Astra International TBK \\
\hline 5 & ASRI & Alam Sutera Realty TBK \\
\hline 6 & BBCA & Bank of Asia TBK PT \\
\hline 7 & BBNI & National Bank of Indonesia (Persero) TBK \\
\hline 8 & BBRI & Bank of Indonesia (Persero) TBK \\
\hline 9 & BMRI & Bank Mandiri (Persero) TBK \\
\hline 10 & BMTR & Global Mediacom TBK PT \\
\hline 11 & BSDE & Bumi Serpong Damai Tbk PT \\
\hline 12 & CPIN & Charoen Pokphan Indonesia Tbk \\
\hline 13 & GGRM & Gudang Garam Tbk \\
\hline 14 & ICBP & Indofood CBP Sukses Makmur Tbk \\
\hline 15 & INDF & Indofood Sukses Makmur Tbk \\
\hline 16 & INTP & Indocement single Perkasa TBK \\
\hline 17 & JSMR & Jasa Marga (Persero) TBK \\
\hline 18 & KLBF & Kalbe Farma Tbk \\
\hline 19 & LPKR & Lippo Karawaci Tbk \\
\hline 20 & LSIP & PP London Sumatera Indonesia TBK \\
\hline 21 & PGAS & State Gas Company (Persero) TBK \\
\hline 22 & PTBA & Bukit Asam coal Mine (Persero) TBK \\
\hline 23 & SMGR & Cement Indonesia (Persero) TBK \\
\hline 24 & TLKM & Telecommunications Indonesia (Persero) TBK \\
\hline 25 & UNTR & United Tractors Tbk \\
\hline 26 & UNVR & Unilever Indonesia TBK \\
\hline
\end{tabular}

The secondary data was used is the annual report of the company. The data was obtained from the Indonesian stock exchange through the official website of www.idx.co.id. The data collection method used in this study is literature research. Literature research is conducted by collecting data and information from a variety of sources that support research, study books, journals, theses, articles, and other data relevant to the variables studied. The profitability and financial leverage were obtained from financial information stated in the annual report. Meanwhile, non-financial information to identify the data of CSR disclosure, content analysis procedure was conducted. In this study, the framework was used to measure CSR disclosure is using Global Reporting Initiative (GRI). 


\section{Results}

\section{Normality and Autocorrelation Test}

Before conducting a regression analysis, the normality test is required. Normality test was addressed to examine whether the data is normally distributed or in other words representing the population. The normality test results are presented in Image 1

Images 1. Test result normality

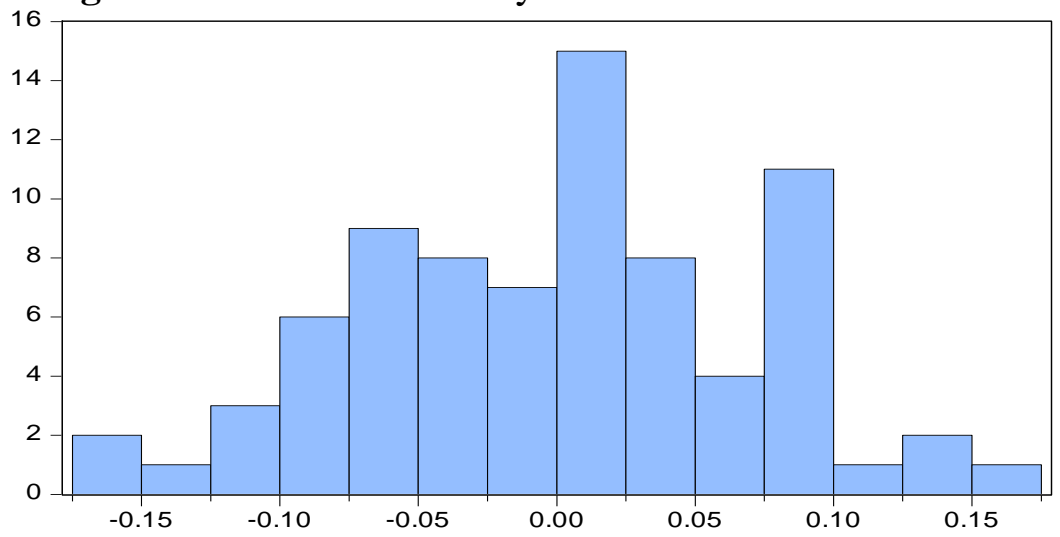

\begin{tabular}{|lr|}
\hline \multicolumn{2}{|l|}{ Series: Residuals } \\
Sample 1 78 \\
Observations 78 \\
Mean & 6.51 e-17 \\
Median & 0.002974 \\
Maximum & 0.172471 \\
Minimum & -0.174063 \\
Std. Dev. & 0.071266 \\
Skewness & -0.021222 \\
Kurtosis & 2.675669 \\
& \\
Jarque-Bera & 0.347724 \\
Probability & 0.840413 \\
\hline
\end{tabular}

Based on information depicted in image 1 , the test result of normality data shows that Jarque - Bera of 0.347724 is smaller than 2 (two) and the Probability value of 0.840413 is higher than the error rate of $5 \%$ or 0.05 . It was concluded that the data was normal distributed so that the data is qualified for regression testing.

The data was used in this study is times series data. In the regression analysis, the autocorrelation test is required to identify whether the data free form

autocorrelation. Autocorrelation is a characteristic of data which shows the degree of similarity between the values of the same variables over successive time intervals. It violates the assumption of instance independence, which underlies most of the conventional models. It generally exists in those types of data-sets in which the data, instead of being randomly selected, are from the same source. The results of autocorrelation is presented in table 4.

Table 4. Autocorrelation test Results

\begin{tabular}{|l|r|l|r|}
\hline R-squared & 0.700404 & Mean dependent var & 0.360000 \\
\hline Adjusted R-squared & 0.688092 & S.D. dependent var & 0.082828 \\
\hline S.E. of regression & 0.046259 & Akaike info criterion & -3.258591 \\
\hline Sum squared resid & 0.156209 & Schwarz criterion & -3.136835 \\
\hline Log-likelihood & 129.4558 & Hannan-Quinn criteria. & -3.209890 \\
\hline F-statistic & 56.88724 & Durbin-Watson stat & 1.965330 \\
\hline Prob(F-statistic) & 0.000000 & \multicolumn{2}{|l}{} \\
\hline
\end{tabular}

Table 4. shows that the autocorrelation test results obtained Durbin-Watson value of 1.965330 . D value $(1.5801)<\mathrm{DW}(1.965330)<4-\mathrm{d}_{\mathrm{U}}$ (1.6851). Based on the information in Table
4, the conclusion is that there is no autocorrelation. Therefore, the data fulfills the requirement for regression analysis. 


\section{Multiple Linear Regression Analyses}

Multiple linear regression analyses were performed to predict the relationship between independent variables and dependent variables. The dependent variables in this study are Corporate Social Responsibility (CSR) as measured by the
CSR INDEX (CSRI) and independent variables in this study is the level of profitability and leverage. Level of profitability was measured using Return On Investment. Meanwhile, Debt to Equity Ratio is proxy to measure leverage. The results of multiple regression is presented in Table 5.

Table 5. Multiple Linear regression results

\begin{tabular}{crrrr}
\hline Variable & Coefficient & Std. Error & t-Statistic & Prob. \\
\hline C & 0.334605 & 0.029967 & 11.16565 & 0.0000 \\
Profitability & 0.263351 & 0.089372 & 2.946669 & 0.0043 \\
Leverage & 0.006667 & 0.005380 & 1.239113 & 0.2193 \\
\hline
\end{tabular}

Based on information stated in Table 5, it indicates that the profitability of companies positively influences the CSR disclosure $(\mathrm{p}<0.05)$. It means that companies with higher profitability tend to disclose CSR information better than the companies with lower profitability. The results consistent with the previous researches that predict the profitability of the firm positively significantly influenced CSR disclosure. However, leverage is failed to prove as a factor to influence CSR disclosure. The result that indicates that leverage is not significant to explain the variance of CSR disclosure is not as expected.

\section{Coefficient of Determination analysis}

Coefficient of determination analysis aims to measure to the extent to which the ability of the model in describing the variation of dependent variables. The value of coefficient of determination is between 0 (zero) to 1 (one) which is $0<\mathrm{R}^{2}$ $<1$. A value approaching 1 (one) means that independent variables provide almost all the information needed to predict the variation of the dependent variable. The results of coefficient determination calculation are presented in Table 6 .

Table 6. Coefficient of determination

\begin{tabular}{lllr}
\hline R-squared & 0.700404 & Mean dependent var & 0.360000 \\
Adjusted R-squared & 0.688092 & S.D. dependent var & 0.082828 \\
S.E. of regression & 0.046259 & Akaike info criterion & -3.258591 \\
Sum squared resid & 0.156209 & Schwarz criterion & -3.136835 \\
Log-likelihood & 129.4558 & Hannan-Quinn criteria. & -3.209890 \\
F-statistic & 56.88724 & Durbin-Watson stat & 1.965330 \\
\hline Prob(F-statistic) & 0.000000 & &
\end{tabular}

Based on information in table 6 , it shows that R-squared value is 0.70040 or $70.04 \%$ It can be concluded that the profitability and Leverage level contributed to the rate of $70.04 \%$ of corporate Social
Responsibility disclosure. The remaining, which is $29.96 \%$, it is explained by other variables outside the research model. The remaining variables are the subject of future research. Even though the leverage is not 
significant to explain the variance of CSR disclosure; however, the model is relative convincing to explain the variance of CSR disclosure ( $70.04 \%)$.

\section{Discussion}

The statistical T-Test (partial testing) indicates a profitability variable that is proxied using a Return On Investment (ROI) ratio affects the Corporate Social Responsibility Disclosure (CSR). The result is consistent with the previous findings by Sari and Hanifa (2017), Gusti and Ida (2015), Rina and Suyanto (2015), and Heni (2013). The statistical T-Test (partial testing ) indicates that the Leverage variable to be proscribed using the Debt to Equity ratio (DER) ratio does not affect Corporate Social Responsibility (CSR). The results of this study is not consistent with the previous research conducted by Rafika Anggraini Putri and Yulius Jogi Christiawan (2014) and I Gusti Agung Arista Pradnyani \& Eka Ardhani Sisdyani (2015). F statistical test (simultaneous testing) provides the result that the profitability variable using the Return On Investment indicator and Leverage using the Debt to Equity Ratio Indicator Influence simultaneously on the disclosure of Corporate Social Responsibility in companies listed on Indonesia Stock exchange period 2013 2015 based on LQ 45 index. The result is consistent with the previous study conducted by Esti (2013), Dini, Willy \& Djusnimar (2017), and Reka, Susfayetti, and Misni (2014)

\section{Conclusion}

Profitability affects the disclosure of Corporate Social Responsibility partially. Leverage does not affect the disclosure of Corporate Social Responsibility. Profitability and Leverage affect the disclosure of Corporate Social responsibility simultaneously. For the next researcher, it is expected to extend the number of samples involved in the study, not only limited to the LQ 45 group. Furthermore, other variables such as company size, stock price, good governance are other relevance variables should be investigated in future research.

\section{References}

Adebayo, Emmanuel. (2000). "Corporate Social Responsibility Disclosure, Corporate Financial, and Social Performance: An Empirical Analysis". DBA, Wayne Huizenga Graduate School of Bussiness and Entrepreneurship, Nova Southeastern University, Fort Lauderdale, FL.

Anggraini, Fr. R. R. 2006. "Pengungkapan Informasi Sosial dan Faktor-Faktor yang mempengaruhi Pengungkapan Informasi Sosial dalam Laporan Keuangan Tahunan (Studi Empiris pada Perusahaan-Perusahaan yang terdaftar di Bursa Efek Jakarta)". Simposium Nasional Akuntansi IX Padang.

Anugerah, Rita., dkk. 2010. Pengaruh Ukuran Perusahaan, Leverage, dan Profitabilitas terhadap Pengungkapan Tanggung Jawa Sosial Perusahaan pada Perusahaan Manufaktur yang Listing di BEI. Jurnal Ekonomi, Vol 18 No 1, Maret.

Arikunto, S. 2010. Prosedur Penelitian Suatu Pendekatan Praktik. Jakarta: Rineka Cipta.

Azheri, Busyra. 2011. Corporate Social Responsibility : Dari Voluntary Menjadi Mandatory. Jakarta : Rajawali Pers.

Brigham, Eugene F dan Houston. 2006. Fundamental of FinancialManagement: Dasar-Dasar 
Manajemen Keuangan. Edisi 10. Jakarta \: Salemba Empat.

Budimanta, A, Prasetijo, A., Rudito, B. 2004. Corporate Social Responsibility, Jawaban bagi Model Pembangunan Indonesia Masa Kini. Jakarta: ICSD.

Cheng, Megawati dan Yulius Jogi Christiawan. 2011. "Pengaruh Pengungkapan Corporate Social Responsibility Terhadap Abnormal Return". Jurnal Akuntansi Keuangan, Vol. 13, No. 1, Hal. 24-36.

Daft, L. Richard, 2012. Era Baru Manajemen. Jakarta: Salemba Empat. Damayanti, Okty. 2013. "Berkat Air Adaro Raih Global CSR Award" http://www.dunia-energi.com/berkatair-adaro-raih-global-csr-awards/

Daniri, M. A. 2005. Good Corporate Governance, Konsep dan Penerapannya dalam Konteks Indonesia. Jakarta : PT. Ray Indonesia.

Darwin, Ali. 2007. Pentingnya Laporan Berkelanjutan. Majalah Akuntansi Indonesia.

Darwin, Ali. 2011. Dari 438 emiten, hanya 25 perusahaan yang membuat laporan berkelanjutan.

Daryono \& Zulhelmy. 2012. "The Effects of Commissioner Board Size, Corporate Leverage, Corporate Size, and Profitability on Information Disclosure of Corporate Social Responsibility: Evidences from Mining Firms in Indonesia”. International Conference on Management Proceeding, 11-12 June 2012, pp.9-17.

Deegan, Craig, et al. 2002. "An Examination of the Corporate Social Environmental Disclosures of BHP from 1983-1997: A Test of Legitimacy Theory". Accounting, Auditing, and Accountability Journal, Vol. 15, No. 3, pp. 312-343.

Dewi, Sofia Prima dan Keni. 2013. Pengaruh Umur Perusahaan,
Profotabilitas, Ukuran Perusahaan dan Leverage terhadap Pengungkapan Tanggung Jawab Sosial Perusahaan. Jurnal Bisnis dan Akuntansi Vol. 15 No. 1, Juni 2013 Hlm. 1-12.

Elka, 2014. "Masih Enggan Membuat Laporan Keuangan?"

Fahmi, Irham, 2011. Analisis Laporan Keuangan. Bandung: Penerbit Alfabeta.

Fraser, Lyn M. dan Aileen Ormiston. 2008. Memahami Laporan Keuangan. Edisi Ke Tujuh. Jakarta : Indeks (terjemahan).

Ghozali, Imam. 2013. Analisis Multivariat dan Ekonometrika: Teori, Konsep, dan Aplikasi dengan Eviews 8. Semarang: Badan Penerbit - Undip.

Gitman, Lawrence. 2008. Principles of Managerial Finance. United States: Pearson Addison Wesley.

Hadi, Nor. 2011. Corporate Social Responsibility. Yogyakarta : Graha Ilmu.

Harahap, Sofayn Syafri. 2008. Analisis Kritis Atas Laporan Keuangan. Jakarta : Raja Grafindo Persada.

Haramain,A.M.2016. "DPR Siapkan UU soal CSR, Perusahaan Akan Dibebankan 2 Persen hingga 3 Persen" https:// nasional. kompas.com / read / 2016 / 04 / 25/09114111/DPR.Siapkan.UU.soal. CSR.Perusahaan.Akan.Dibebankan.2 persen.hingga.3 persen.

http://ekonomi.kompasiana.com/bisnis/210 4/04/21/masih-enggan-membuatlaporan keberlanjutan--648392.html

https://www.google.co.id/amp/amp.kontan .co.id/news/dari-438-emiten-hanya25-perusahaan-yang-membuatlaporan-berkelanjutan

International Organization for Standardization (ISO) 26000 tentang Guidance on Social Responsibility yang dikeluarkan pada 1 November 2010 . 
Irawati, Susan. 2006. Manajemen Keuangan. Jakarta : Pustaka.

Juhmani, Omar. 2014. Determinants Of Corporate Social Dan Environmental Disclosure On Website: The Case Of Bahrain. Universal Journal of Accounting and Finance. Vol. 2. No. 4. Pp. 77-87.

Kamil, Ahmad \& Antonius Herusetya. 2012. Pengaruh Karakteristik Perusahaan Terhadap Luas Pengungkapan Kegiatan Corporate Social Responsibility. Media Riset Akuntansi Vol. 2 No. 1.

Kusumah, Asep. 2018. https:// www.republika.co.id/ berita/ nasional / daerah /18/04/29/p7ye53409buang-limbah-ke-sungai-satuperusahaan-di-bandung-disanksi.

Lako, Andreas. 2011. Dekonstruksi CSR dan Reformasi Paradigma Bisnis dan Akuntansi. Jakarta : Erlangga.

Maiyarni, Reka, Susfayetti dan Misni Erwati. 2014. Pengaruh Profitabilitas, Ukuran Perusahaan, Likuiditas dan Leverage terhadap Pengungkapan Corporate Social Responsibility (CSR) pada Perusahaan LQ-45 yang Terdaftar di Bursa Efek Indonesia Periode 2009-2012. ISSN: 19794851. Jurnal Cakrawala Akuntansi. Volume 6. Nomor 1. Halaman: 79-94.

Masnila, Nelly. 2010. "Corporate Social Responsibility: Sebuah Pandangan dari Sudut Akuntansi”. Politeknik Negeri Sriwijaya, Palembang.

Melani,A. 2014. Harga Batu Bara Anjlok, Laba Adaro Energy Turun 40\%. https://www.google.co.id/amp/20211 40/harga-batu-bara-anjlok-labaadaro-energy-turun-40

Mia, P. \& Al Mamun, A. 2011. Corporate Social Disclosure during the Global Financial Crisis. International Journal of Economics and Finances, 3(6), 174-187.

Munawir, H.S. 2004. Analisa Laporan Keuangan. Yogyakarta : Liberty.
Pedoman Global Reporting Initiative G4 tahun 2013 versi Bahasa Indonesia.

Pernyataan Standar Akuntansi Keuangan No. 1 revisi 2017

Rahman, Arief dan Kurnia Nur Widyasari. 2008. The Analysis of Company Characteristic Influence Toward CSR Disclosure: Empirical Evidence of Manufacturing Companies Listed in JSX. JAAI volume 12 No.1, Juni 2008: 25-35.

Rusdin. 2008. Pasar Modal : Teori, Masalah dan Kebijakan dalam Praktik. Bandung : Alfabeta.

Sartono, Agus. 2010. Manajemen Keuangan Teori dan Aplikasi. Edisi 4. Yogyakarta : BPFE.

Scott, W. R. 2009. "Financial Accounting Theory. Fifth Edition". Toronto: Pearson Prentice Hall.

Sekaran, Uma. 2017. Metode Penelitian Untuk Bsnis. Edisi 6. Jakarta: Salemba Empat

Sembiring, Eddy, 2005. Karakteristik Perusahaan dan Pengungkapan Tanggung Jawab Sosial: Study Empiris pada Perusahaan yang Tercatat di BEJ. Simposium Nasional Akuntansi VIII. Solo.

Siegel, Joel G. dan Jae K .Shim, 1999. Kamus Istilah Akuntansi. Jakarta : Elex Media Komputindo

Sugiyono. 2012. Metode Penelitian Bisnis. Bandung: CV Alfabeta.

Sumarni, Murti \& Salamah Wahyuni. 2006. Metodologi Penelitian Bisnis. Yogyakarta: Penerbit Andi Yogyakarta.

Susilatri, dkk. 2011. Pengaruh Leverage, Profitabilitas, Size, Umur Perusahaan, dan Ukuran Dewan Komisaris Terhadap Pengungkapan Tanggung Jawab Sosial Perusahaan. Pekbis Jurnal Vol.3: 412-428.

Titisari, Kartika Hendra, dkk. 2010. Corporate Social Responsibility dan Kinerja Perusahaan. Simposium Nasional Akuntansi XIII. 
Umar, Husein. 2002. Metodologi Penelitian Aplikasi dalam Pemasaran. Edisi II, Jakarta: PT. Gramedia Pustaka Utama.

Undang-Undang Republik Indonesia No. 32 tahun 2009 tentang Perlindungan Dan Pengelolaan Lingkungan Hidup. Undang-Undang Republik Indonesia No. 40 tahun 2007 tentang Perseroan Terbatas.

Undang-Undang Republik Indonesia tentang Perseroan Terbatas pasal 66 ayat (2).

Undang-Undang Republik Indonesia tentang Perseroan Terbatas pasal 74 ayat (1).

Untung, Hendrik Budi. 2008. Corporate Social Responsibility. Jakarta : Sinar Grafika.

Van Horne, James C. W. John M. Jr. 2005. Prinsip-Prinsip Manajemen Keuangan. Edisi Bahasa Indonesia terjemahan Dewi Fitriasari dan Deny Arnos Kwary. Jakarta : Salemba Empat.

Wardani, Nurul Kusuma. 2013. Pengaruh Karakteristik Perusahaan terhadap Pengungkapan Corporate Social Responsibility (CSR) pada Perusahaan Manufaktur yang terdaftar di Bursa Efek Indonesia tahun 2009-2011). Diponegoro Journal of Accounting Vol. 2, No. 2, Tahun 2013, Halaman 1-15.

Weston, J. Fred dan Eugene F Brigham. 2001. Manajemen Keuangan. Jakarta: Erlangga.

Wijaya, Maria. 2012. Faktor-faktor yang Mempengaruhi Penungkapan Tanggung Jawab Sosial Perusahaan Manufaktuf yang Terdaftar di Bursa Efek Indonesia. Jurnal Ilmiah Mahasiswa Akuntansi. Vol 1, No.1, Januari 2012.

Yuliana, R., B. Purnomosidhi \& E.G. Sukoharsono. 2008. Pengaruh Karakteristik Perusahaan terhadap Pengungkapan Corporate Social Responsibility (CSR) dan
Dampaknya Terhadap Reaksi Investor. Jurnal Akuntansi dan Keuangan Indonesia, 5(2), 245-276. Zulfahmi. 2013. Hanya 10 Persen Perusahaan di NTB Laporkan CSR http://arsip.lombokita.com/kabar/han ya-10-persen-perusahaan-di-ntblaporkan-csr 